\title{
Analisa dan Perancangan Aplikasi Pengolahan Nilai Siswa Pada SMP Negeri 10 Pangkalpinang
}

\author{
Marini \\ Jurusan Sistem Informasi \\ STMIK ATMA LUHUR \\ Pangkalpinang \\ arinimarini44@atmaluhur.ac.id
}

\begin{abstract}
Abstrak - Proses pengelolaan nilai pada SMP Negeri 10 pangkalpinang ini masih belum terkomputerisasi sehingga banyak mengalami keterlambatan dalam penyajian data terutama dalam data siswa, data nilai, rekap nilai, raport dan laporan. Untuk itu penulis mencoba mengatasi dengan melakukan pengendalian sistem pengolahan nilai dengan cara membuat sistem terkomputerisasi yaitu sistem pengelolaan nilai dengan tujuan supaya mengefisienkan dari segi waktu dan biaya. Adapun hasil sistem usulah yang ingin dicapai dengan adanya sistem terkomputerisasi ini supaya mempermudah dalam pengolahan data, pencarian data nilai, penyimpanan data dan mempelajari tata cara pengolahan data yang lebih efisien, dan mengimplementasikan sistem pengolahan data nilai. Metode yang digunakan dalam tahap pengolahan data nilai ini adalah menggunakan konsep UML, pengelolaan data base menggunakan MQSL. Dalam datahap perancangan menggunakan pemrograman visual versi 8 .
\end{abstract}

Kata Kunci-Pengelaan nilai, sistem informasi, konsep uml, database acces, mqsl, visual basic versi 8 .

\section{PENDAHULUAN}

Sistem informasi pengolahan nilai siswa dengan menggunakan sistem terkomputerisasi akan memberikan kemudahan dalam penyajian data nilai,data guru, dan laporan. Sehingga membantu mempercepat dalam menyampaikan informasi. Permasalahan dalam pengolahan nilai pada smp negeri 10 pangkalpinang ini sering megalami kertlambatan dalam penyajian data guru, data nilai dan laporan, sering mengalami kekesulitan daam pencarian data pengolahan nilai, sering terjadi kesalahan dalam perhitungan nilai dan pengisiannya. Berdasarkan dari beberapa kesulitan yang sering terjadi pada smp negeri 10 ini penulis bertujuan akan mengatasi kesulitan yang terjadi dengan mengusulkan sistem yang terkomputerisai yaitu sistem pengolahan nilai siswa. Dengan adanya sistem tersebut diharapkan nantinya pengolahan data nilai siswa lebih terorganisir sehingga mempermudah cara kerja dan meningkatkan efisiensi kerja, mengimplementasi sistem pegolahan nilai, mempromosikan sistem pengolahan nilai. Metode yang digunakan untuk merancang aplikasi menggunakan bahasa pemrograman visual basic 8 . Adapun tahap analisa yang digunakan menggunakan konsep uml yaitu menggunakan diagram activity diagram use case diagran dan tahan perancangan dokumen mengunkana diagram ERD, perancangan data base menggunakan mocrosoft access.

\section{LANDASAN TEORI}

A. Konsep dasar Informasi

Menurut Tata Sutabri “informasi adalah sebuah istilah yang tepat dalam pemakaian umum. Informasi dapat mengenai data mentah, data tersusun, kapasitas sebuah saluran komunikasi dan lain sebagainya" [1]. Informasi merupakan proses lebih lanjut dari data yang sudah memiliki nilai tambah. Menurut Tata Sutabri informasi dapat dikelompokan menjadi 3 bagian, yaitu : Informasi strategis : Informasi ini digunakan untuk mengambil keputusan jangka panjang, yang mencakup informasi eksternal, rencana perluasan perusahaan, dan sebagainya. Informasi taktis : Informasi ini dibutuhkan untuk mengambil keputusan jangka menengah, seperti informasi tren penjualan yang dapat dimanfaatkan untuk menyusun rencana penjualan. Informasi teknis : Informasi ini dibutuhkan untuk keperluan operasional sehari-hari, seperti informasi persediaan stock, retur penjualan, dan laporan kas harian [1].

\section{B. Definisi Sistem Informasi}

Menurut Tata Sutabri dalam bukunya, "Informasi adalah data yang telah diklasifikasikan atau diinterpretasi untuk digunakan dalam proses pengambilan keputusan"[1]. Sistem pengolahan informasi mengolah data menjadi informasi atau tepatnya mengolah data dari bentuk tak berguna menjadi berguna bagi penerimannya. Nilai informasi berhubungan dengan keputusan, maka informasi menjadi tidak diperlukan keputusan bila tidak ada pilihan atau keputusan. Keputusan dapat berkisar dari keputusan berulang sederhana sampai keputusan strategis jangka panjang. Nilai informasi dilukiskan paling berarti dalam konteks sebuah keputusan.

\section{Konsep Dasar Sistem Informasi}

Telah diketahui informasi merupakan hal-hal yang sangat penting bagi pengambilan keputusan. Darimana informasi tersebut didapat ? Informasi bisa diperoleh dari sistem informasi. Menurut Tata Sutabri, " sistem informasi adalah suatu sistem di dalam suatu organisasi yang mempertemukan 
kebutuhan pengolahan transaksi harian yang mendukung fungsi operasi organisasi yang bersifat manajerial dengan kegiatan strategi dari suatu organisasi untuk dapat menyediakan kepada pihak luar tertentu dengan laporanlaporan yang diperlukan”[1].

\section{Komponenen dan jenis sistem informasi}

Sistem informasi terdiri dari komponen-komponen yang disebut blok bangunan (building block), yang terdiri dari blok masukan, blok model, blok keluaran, blok teknologi, blok basis data, blok kendali. Sebagai suatu sistem, keenam blok tersebut masing-masing saling berinteraksi satu dengan yang lain membentuk suatu kesatuan untuk mencapai sasaran. Berikut ini adalah komponen-kompone menurut Tata Sutabri [1]

1. Blok masukan (input block) :

Input mewakili data yang masuk kedalam sistem informasi. Input yang dimaksud adalah metode dan media untuk menangkap data yang akan dimasukan, yang dapat berupa dokumen-dokumen dasar.

2. Blok model (model block)

Blok ini terdiri dari kombinasi prosedur, logika, dan model matematik yang akan memanipulasi data input dan data yang tersimpan di basis data dengan cara yang sudah tertentu untuk menghasilkan keluaran yang diinginkan.

3. Blok keluaran (output block)

Produk dari sistem informasi adalah keluaran yang merupakan informasi yang berkualitas dan dokumentasi yang berguna untuk semua tingkatan manajemen serta semua pemakai sistem.

4. Blok teknologi (technology block)

Teknolgi merupakan "tool box" dalam sistem informasi. Teknologi digunakan untuk menerima input, menjalankan model, menyimpan dan mengakses data, menghasilkan dan mengirimkan keluaran, dan membantu pengendalian dari sistem secara keseluruhan. Teknolgi terdiri dari 3 (tiga) bagian utama, yaitu teknisi (brainware), perangkat lunak (software), dan perangkat keras (hardware).

5. Blok basis data (database block)

Basis data (database) merupakan kumpulan data yang saling berkaitan dan berhubungan sastu sama lain, tersimpan di perangkat keras komputer dan menggunakan perangkat lunak untuk memanipulasinya. Data perlu disimpan dalam basis data untuk keperluan penyediaan informasi lebih lanjut. Data dalam basis data perlu diorganisasikan sedemikian rupa supaya informasi yang dihasilkan berkualitas. Organisasi basis data yang baik juga berguna untuk efesiensi kapasitas penyimpanannya. Basis data diakses atau dimanipulasi menggunakan perangkat lunak paket yang disebut DBMS (Database Management Sytem).

6. Blok kendali (control block)

Banyak hal yang dapat merusak sistem informasi, seperti bencana alam, api, temperatur, air, debu, kecurangan-kecurangan, kegagalan-kegagalan sistem itu sendiri, ketidak efisienan, sabotase, dan lain sebagainya. Beberapa pengendalian perlu dirancang dan diterapkan untuk meyakinkan bahwa hal-hal yang dapat merusak sistem dapat dicegah ataupun bila terlanjur terjadi kesalahan-kesalahan dapat langsung cepat diatasi.

Secara teori, komputer komputer tidak harus digunakan didalam sistem, tetapi tidaklah mungkin suatu sistem yang kompleks dapat berfungsi melibatkan elemen nonkomputer dan elemen komputer. Berikut tipe sistem informasi menurut Tata Sutabri [1] :
a. Sistem informasi akuntasi
b. Sistem informasi pemasaran
c. Sistem informasi manajemene persediaan
d. Sistem informasi personalia
e. Sistem informasi didtribusi
f. Sistem informasi pembelian
g. Sistem informasi kekayaan
h. Sistem informasi analisis kredit
i. Sistem informasi penelitian dan pengembangan
j. Sistem informasi teknik

\section{E. Konsep UML (Unified Modelling Language)}

UML (Unified Modeling Language) adalah bahasa pemodelan untuk sistem atau perangkat lunak yang berparadigma (berorientasi objek). Pemodelan (modeling) sesungguhnya digunakan untuk penyederhanaan permasalahan-permasalahan yang kompleks sedemikian rupa sehingga lebih mudah dipelajari dan dipahami[2]. Berdasarkan pendapat yang dikemukakan diatas dapat ditarik kesimpulan bahwa Unified Modelling Language (UML) adalah sebuah bahasa yang berdasarkan grafik atau gambar untuk menvisualisasikan, menspesifikasikan, membangun dan pendokumentasian dari sebuah sistem pengembangan perangkat lunak berbasis objek (Object Oriented Programming).

Pendekatan dalam analisa berorientasi objek dilengkapi dengan alat-alat dan teknik-teknik yang dibutuhkan dalam pengembangan sistem, sehingga hasil akhir dari sistem yang dikembangkan akan didaptkan sistem yang dapat terdefinisi dengan baik dan jelas. Maka analisa berorientasi objek akan dilengkapi dengan alat dan teknik didalam mengembangkan sistem.

Alat bantu yang digunakan dalam analisa beriorientasi objek antara lain :

\section{Activity Diagram.}

Menurut munawar, "Activity Diagram adalah teknik untuk mendeskripsikan logika prosedural, proses bisnis dan aliran kerja dalam flowchart, akan tetapi perbedaannya dengan 
flowchart adalah Activity Diagram bisa mendukung perilaku paralel sedangkan flowchart tidak bisa" [3]. Simbol-simbol yang sering digunakan pada saat pembuatan Activity Diagram adalah sebagai berikut :

a. Start Point, diletakan pada pojok kiri atas dan menggambarkan awal dari aktivitas

b. End Point, menggambarkan akhir dari aktivitas

c. Activity, menggambarkan suatu proses / kegiatan bisnis

Jenis-jenis activity :

1) Black hole activities

Ada masukan dan tidak ada masukan, biasanya digunakan bila dikehendaki ada 1 atau lebih transisi.

2) Miracle activities

Tidak ada masukan tetapi ada keluaranya, biasanya dipakai pada wakti start point dan dikehendaki ada 1 atau lebih transisi.

3) Parallel activities

Suatu activity yang berjalan secara berbarengan. Dan terdiri dari : Fork (Percabangan), digunakan untuk menunjukan kegiatan yang dilakukan secara pararel atau untuk menggabungkan dua kegiatan pararel menjadi satu, Join (Penggabungan), menunjukan adanya dekomposisi.

4) Decision Points, menggambarkan pilihan untuk pengambilan keputusan, true atau false.

5) Guards (Kunci), sebuah kondisi benar sewaktu melewati sebuah transisi, harus konsisten dan tidak overlap.

6) Swimlane, pembagian activity diagram untuk menunjukan siapa melakukan apa.

\section{Use Case Diagram}

Menurut Jeffery, "Use Case Diagram, suatu diagram yang melukiskan interaksi antara sistem dengan para pemakai. Dengan kala lain, use cesa diagram dengan nyata menguraikan siapa saja yang akan menggunakan sistem dan dengan cara apa pemakai dapat saling berhubungan dengan sistem" [4]. Use case diagram terdiri dari :

\section{1) Use Case}

Menurut Munawar, "use case adalah deskripsi fungsi dari sebuah sistem dari perspektif pengguna. Use case bekerja dengan cara mendeskripsikan tipikal interaksi antara user (pengguna) sebuah sistem dengan sistemnya sendiri melalui sebuah cerita bagaimana sebuah sistem dipakai. Penamaan use case sesuai dengan tujuan yang dicapai dari hasil interaksinya dengan actor. Use case biasanya menggunakan kata kerja" [3].

\section{2) Actor}

Menurut Munawar, "actor adalah abstraction dari orang atau sistem yang lain mengaktifkan dari target sistem. Untuk mengidentifikasikan actor, harus ditentukan pembagian tenaga kerja dan tugas-tugas yang berkaitan dengan pera pada konteks target sistem. Orang atau sistem bisa muncul dalam beberapa peran. Perlu dicatat bahwa actor berinteraksi dengan use case, tetapi tidak memiliki kontrol terhadap use case" [3].

\section{3) Relationship}

a. Relasi antara actor dengan use case

b. Menurut Jeffery, "Relasi (Relationship) antara use case pada use case diagram digambarkan dalam bentik garis. Relasi antara actor dengan use case disebut dengan asosiasi, asosiasi adala sebuah relasi antara actor dengan use case dimana sebuah interaksi terjadi diantara mereka" [4].

c. Relasi Use case ke use case

Selain terdapat relasi-relasi antara actor dan use case, juga terdapat relasi-relasi antara use case dengan use case. Ada beberapa jenis relasi antara use case dengan use case, diantaranya :

(1) Include, digunakan untuk menggambarkan bahwa suatu use case seluruhnya merupakan fungsionalitas dari use case lainnya.

(2) Extend, digunakan untuk menunjukan bahwa satu use case merupakan tambahan fungsional dari use case yang lain jika kondisi atau syarat tertentu yang dipenuhi.

\section{F. Perancangan berorientasi object}

Menurut Jeffery L. Whitten "Perancangan sistem berorientasi obyek (Object-Oriented Design) adalah suatu pendekatan yang digunakan untuk mensfesifikasikan kebutuhan - kebutuhan sistem dengan mengkolaborasikan obyek, atribut -atribut dan metode - metode yang ada"[4].

\section{ERD ( Entity Relationship Diagram )}

Entity Relationship Diagram (ERD) atau 'Diagram Hubungan Antar Entitas' merupakan hasil akhir dari proses analisis terhadap sistem yang ditinjau yang dilakukan oleh seorang analis sistem". Yang pertama kali mendeskripsikan diagram-ER adalah Peter Chan yang dibuat sebagai bagian dari perangkat lunak case. Model ERD adalah suatu penyajian data dengan menggunakan entity dan relationship. Diagram-ER menggambarkan hubungan antara data yang ada dan tidak menggambarkan proses - proses yang terjadi. Simbol - simbol / notasi yang biasa digunakan dalam ERD, antara lain :

a. Menurut Jeffery L.Whitten "Entity (entitas) adalah sebuah kelas dari orang, tempat obyek, kejadian dan sebagainya atau sebuah konsep yang mana kita perlukan untuk menagkap dan menyimpan data"[4]. Pada entity terdapat dua jenis, yaitu :

1) Strong Entity adalah entity yang memiliki primary key.

2) Weak Entity adalah suatu entity yang tidak memiliki primary key dan keberadaan 
entity tersebut tergantung dari keberadaan entity lain. Entity yang merupakan induknya disebut identifying owner dan relasinya disebut identifying relationship.

a. Relationship ( Hubungan / relasi ), menunjukkan adanya hubungan diantara sejumlah entitas yang berbeda.

b. Cardinality / Kardinalitas

Cardinality adalah tingkat hubungan atau derajat relasi. Tingkat cardinality yang terjadi pada sebuah ERD adalah sebagai berikut :

1) One To One ( $1: 1)$

Hubungan relasi one to one yaitu setiap entitas pada himpunan entitas A berhubungan paling banyak dengan satu entitas pada himpunan entitas B.

2) One To Many ( $1: \mathrm{M}$ )

Setiap entitas pada himpunan entitas A dapat berhubungan dengan banyak entitas pada himpunan entitas $\mathrm{B}$, tetapi setiap entitas pada entitas $\mathrm{B}$ dapat berhubungan dengan satu entitas pada himpunan entitas A.

3) Many To One ( $\mathrm{M}: 1$ )

Setiap entitas pada himpunan entitas B dapat berhubungan dengan banyak entitas pada himpunan entitas A, tetapi setiap entitas pada entitas A dapat berhubungan dengan satu entitas pada himpunan entitas B.

4) Many To Many ( M : M )

Setiap entitas pada himpunan entitas A dapat berhubungan dengan banyak entitas pada himpunan entitas B, begitu juga sebaliknya.

\section{LRS (Logical Record Structure)}

Diagram-ER (ERD) harus dikonversi kebentuk structure (struktur record secara logik). Sebuah model sistem yang digambarkan dengan sebuah Diagram-ER akan mengikuti pola/aturan pemodelan tertentu. Dalam kaitannya dengan konversi ke LRS, maka perubahan yang terjadi adalah mengikuti aturan-aturan berikut ini :

1. Setiap entitas akan diubah kebentuk kotak

2. Sebuah relationship kadang disatukan dalam sebuah kotak bersama

entitas jika hubungan yang terjadi pada Diagram-ER 1:M (relasi bersatu dengan cardinality $\mathrm{M}$ ) atau tingkat hubungan 1:1 (relasi bersatu dengan cardinality yang paling membutuhkan referensi), sebuah relationship dipisah dalam sebuah kotak tersendiri jika tingkat hubungannya M:N (Many to many).

\section{METODOLOGI PENELITIAN}

Metodologi penelitian merupakan taha-tahap penelitian yang harus diterapkan sebelum melakukan pemecahan masalah, dalam menganalisa digunakan metode-metode sebagai berikut :

a. Metodologi Pengumpulan Data

Dalam menyelesaikan laporan penelitian ini penulis menggunakan beberapa metode penelitian di antaranya :

\section{1) Studi Literatur}

Metode yang dipakai untuk mengumpulkan data yang sifatnya teoritis dengan membaca buku-buku atau literatur, jurnal, paper, dan bacaan-bacaan yang ada kaitannya dengan skripsi ini atau sistem akademik dan sistem pendidikan.

2) Observasi

Obrservasi merupakan salah satu teknik pengumpulan data yang tidak hanya mengukur sikap dari responden (wawancara) namun juga dapat digunakan untuk merekam berbagai fenomena yang terjadi (situasi, kondisi). Teknik ini digunakan bila penelitian ditujukan untuk mempelajari perilaku manusia, proses kerja, gejala-gejala alam dan dilakukan pada responden yang tidak terlalu besar.

3) Wawancara

Wawancara merupakan teknik pengumpulan data yang dilakukan melalui tatap muka dan tanya jawab langsung antara pengumpul data maupun peneliti terhadap nara sumber atau sumber data.

4) Dokumen

Pengambilan data melalui dokumen tertulis mamupun elektronik dari lembaga/institusi, dokumen diperlukan untuk mendukung kelengkapan data yang lain.

5) Analisa Sistem

Kegiatan yang dilakukan tahap ini yaitu menganalisa sistem yang ada, mempelajari dan mengetahui apa yang akan dikerjakan sistem yang ada. Menspesifikasikan sistem, yaitu perincian masukan yang digunakan, database yang ada, proses yang dilakukan dan keluaran yang dihasilkan. Adapun tahapan-tahapan pada analisa sistem yaitu :

a) Activity Diagram

Activity Diagram digunakan untuk memodelkan alur kerja atau work flow sebuah proses bisnis dan urutan aktivitas didalam sebuah proses.

b) Use Case Diagram

Diagram yang digunakan untuk menggambarkan interaksi antara user dengan sistem. 
c) Use Case Description

Use Case Description digunakan untuk mendeskripsikan secara rinci mengenai Use Case Diagram dari sistem yang diusul.

6) Perancangan Sistem

Tahapan perancangan sistem adalah merancang sistem secara rinci, berdasarkan hasil analisa yang ada, sehingga menghasilkan model baru yang akan diusulkan, dengan disertai rancangan database dan spesifikasi program. Alat-alat yang digunakan dalam tahap ini adalah :

a) Entity Relationship Diagram (ERD)

$E R D$ biasa digunakan untuk mengembangkan inisial dari desain basis data, ERD juga menggambarkan hubungan antara data yang ada didalam suatu sistem.

b) Logical Record Structure (LRS)

$L R S$ terdiri dari link-link diantara tipe record. Link ini menunjukkan arah dari satu tipe record lainnya.

c) Tabel

Tabel digunakan untuk mengisi informasi mengenai sebuah entitas yaitu berupa atribut.

d) Spesifikasi Basis Data

Spesifikasi Basis Data digunakan untuk menjelaskan tipe data yang ada pada model konseptual secara detail.

e) Sequence Diagram

Sequence Diagram menggambarkan interaksi antar obyek didalam dan disekitar sistem (termasuk pengguna, display, dan sebagainya) berupa message yang digambarkan terhadap waktu.

\section{f) Class Diagram}

Class Diagram menggambarkan struktur dan deskripsi class, package, dan obyek beserta hubungan satu sama lain seperti containtment, pewarisan, asosiasi, dan lain-lain.

\section{PEMBAHASAN DAN HASIL}

A. Analisa Proses kegiatan sistem Pengelolaan Nilai yang ada.

Proses sistem informasi pengelolaan nilai pada SMP Negeri 10 Pangkalpinang adalah sebagai berikut :

1. Guru mata pelajaran membuat rekap daftar nilai yang akan diserahkan ke wali kelas.

2. Wali kelas mengisi nilai raport kemudian meminta tanda tangan ke kepala sekolah.

3. Wali kelas akan menyerahkan raport kepada siswa.

\section{B. Desain Sistem}

1. Desain Sistem

Tujuan dari sistem yang diusulkan supaya membuat sistem terkomputerisasi untuk mendukung pengolahan data yang dilakukan secara manual, mempermudah pencarian data terutama dalam pengolahan nilai, dan mempermudah penyajian data nilai siswa serta pengamanan penyimpanan data. Adapun sistem yang diusulkan dapat digambarkan pada diagram activity diagram, Use case, perancangan data Base.

2. Desain sistem yang diusulkan

Dengan adanya sistem yang diusulkan ini supaya adanya perubahan-perubahan terutama pada sistem inputan nilai siswa, rekapan nilai siswa, proses pengisian nilai raport akan dikerjakan lebih cepat, efisiensi waktu dan keamanan penyimpanan nilai siswa. Dalam sistem yang diusulkan akan digambarkan dalam sebuah diagram activity diagram, use case diagram dan perancangan data base.

Adapun aliran sistem informasi proses sistem pengolahan nilai dapat dilihat pada gambar 1 dibawah ini

a. Activity Diagram diagram proses pengisian raport siswa.

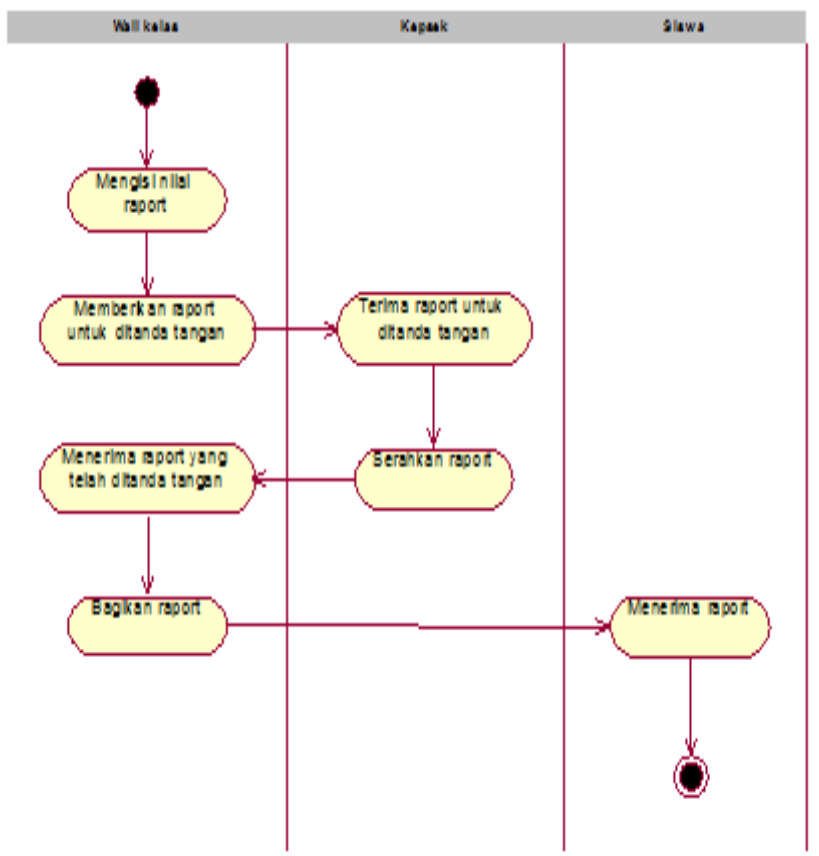

Gambar. 1 Activity Diagram proses pengisian rekap nilai raport dari data guru dan proses penyerahan rapart

b. Use Case Diagram

Sistem usulan untuk proses pengerjaan aliran sistem pengolahan pengisian data raport yang dilakukan oleh use (yang menjalankan sistem) penulis gambarkan pada use case diagram dapat dilihat pada gambar 2 dibawah ini. 


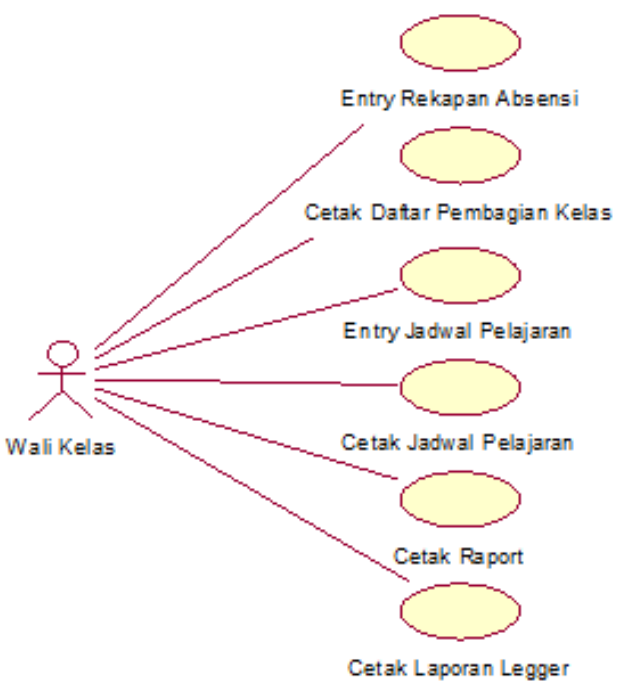

Gambar.2 Use Case Diagram yang digunakan untuk melihat proses pengerjaan sistem yang dilakukan oleh seorang user yang berhubungan dengan aktor yang terlibat dalam sistem pengelolahan nilai.

\section{Perancangan Data Base}

Perancangan Data base penulis usulkan untuk penyimpanan data base yang pakai untuk sistem pengelolaan nilai. Adapun data base yang dirancang penulis dapat dilihat pada gambar 3 dibawah ini.

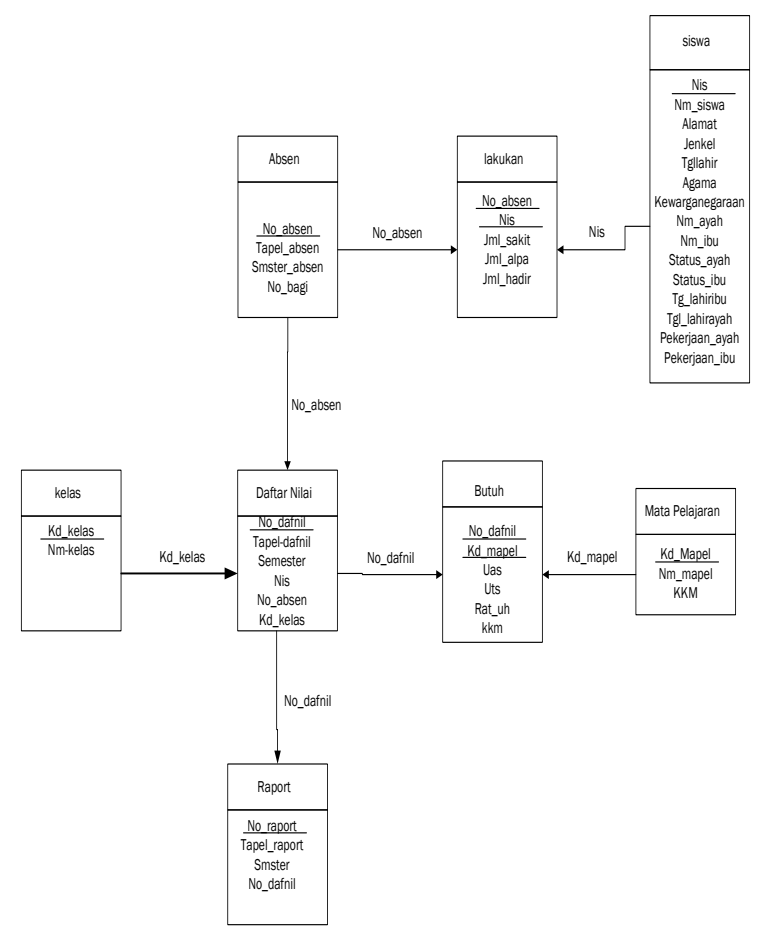

Gambar.3 Logical Record Structure menyatakan data base dari sistem pengolahan nilai
C. Hasil Desain Input sistem baru

Penulis mengusulkan sistem yang lebih baik untuk sistem informasi yang mudah dilakukan sistem pengerjaannya. Rancangan desain Output ini buat untuk melakukan interaksi bagi pengguna sistem dengan sistem itu sendiri. Rancangan untuk sistem input untuk data siswa, data nilai, dan raport.

\section{Desain menu awal}

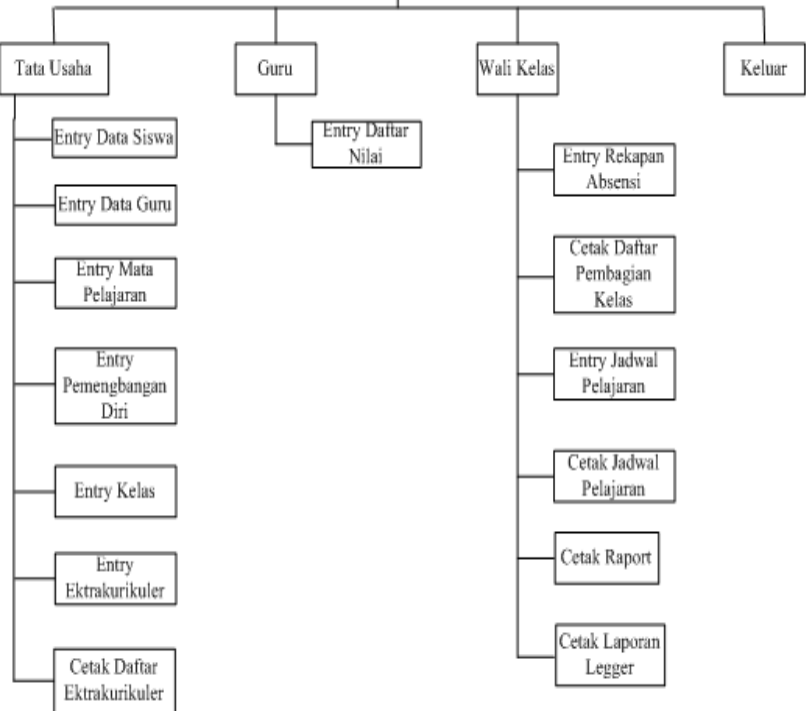

\section{Desain Input data siswa}

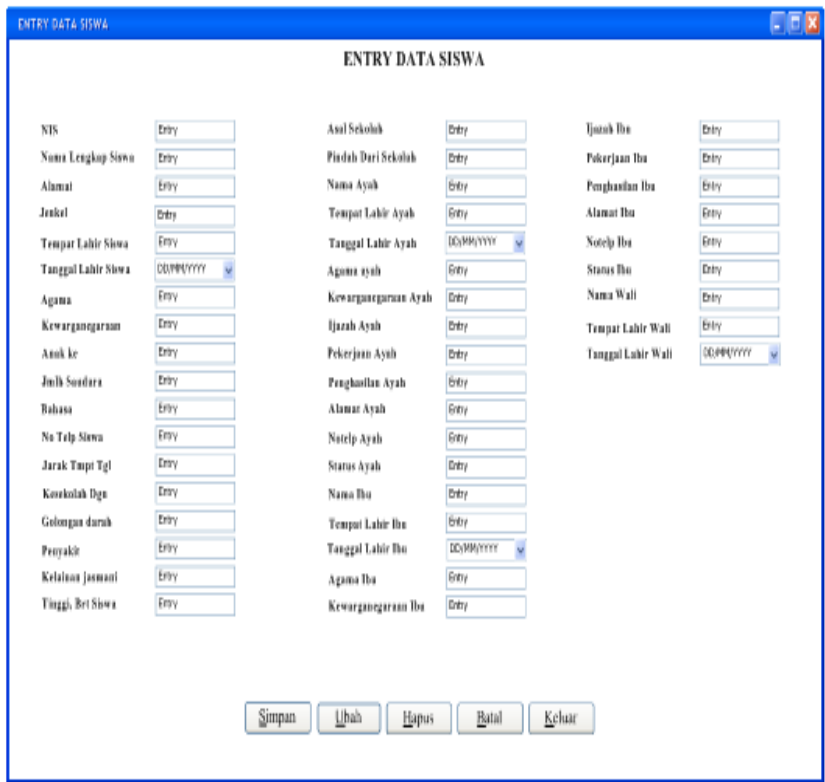

Gambar. 4 Rancangan Antar Muka struktur tampilan implementasi sistem pegelolaan nilai 
3. Desain Input data mata pelajaran

ENTRY MATA PELAJARAN

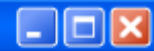

\section{ENTRY MATA PELAJARAN}

\begin{tabular}{ll|} 
Kode Mapel & Auto \\
Nama Mapel & Entry \\
\hline Kkm & Entry \\
\hline
\end{tabular}

Simpan $\underline{\text { Ubah }}$ Hapus

Batal $\underline{\text { Keluar }}$

Gambar.5 Rancangan Data Mata Pelajaran yang digunakan untuk menginput data mata pelajaran

4. Desain input data nilai raport.

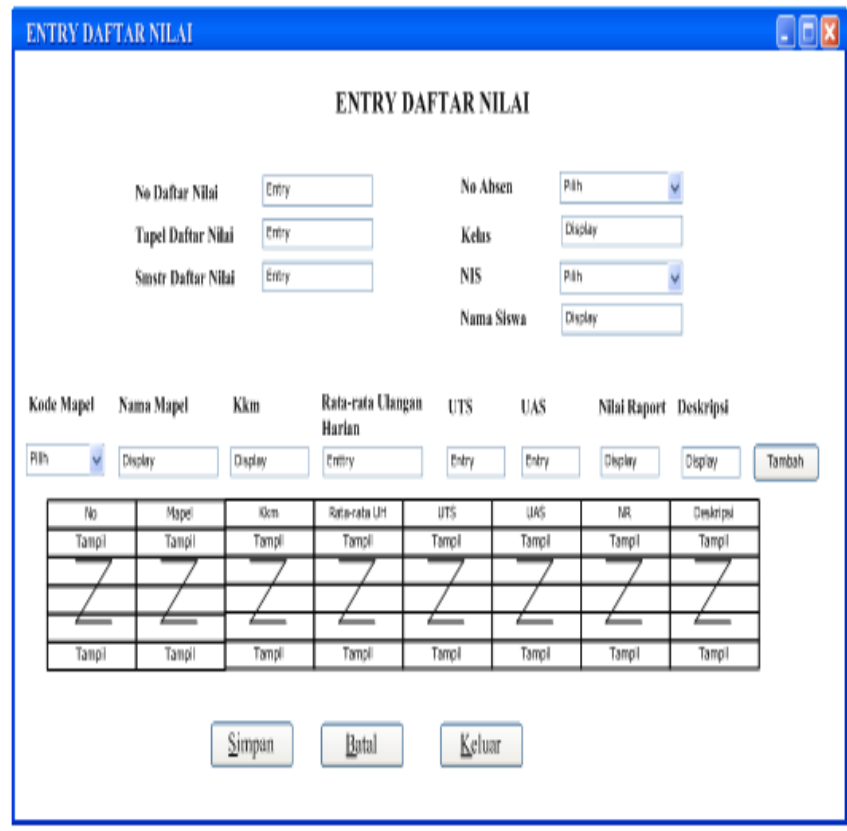

Gambar.6 Rancangan data daftar nilai yang digunakan untuk mengentri data nilai

D. Hasil desain output sistem baru

Hasil output sistem usulan yang baru dibawah ini berfungsi untuk melihat hasil inputan siswa yang sudah daftar dapat dilihat pada gambar 7 dan gambar 8 dibawah ini

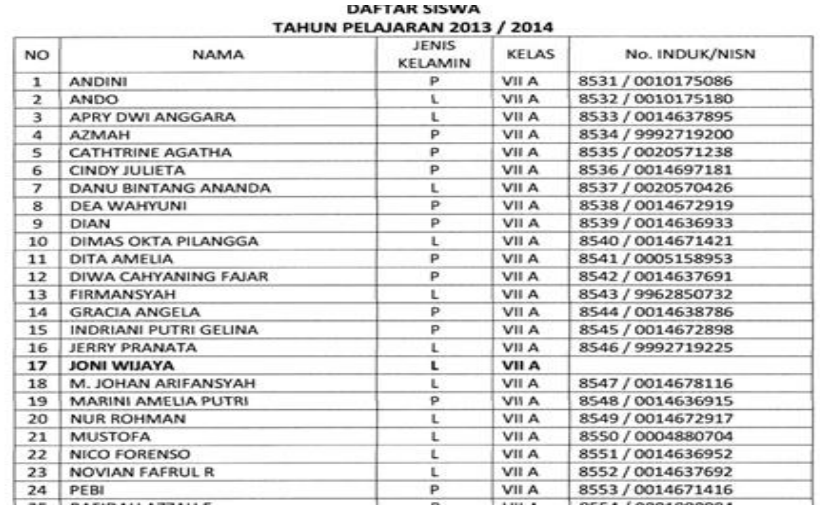

Gambar.7 Rancangan data daftar nilai yang digunakan untuk mengentri data daftar siswa

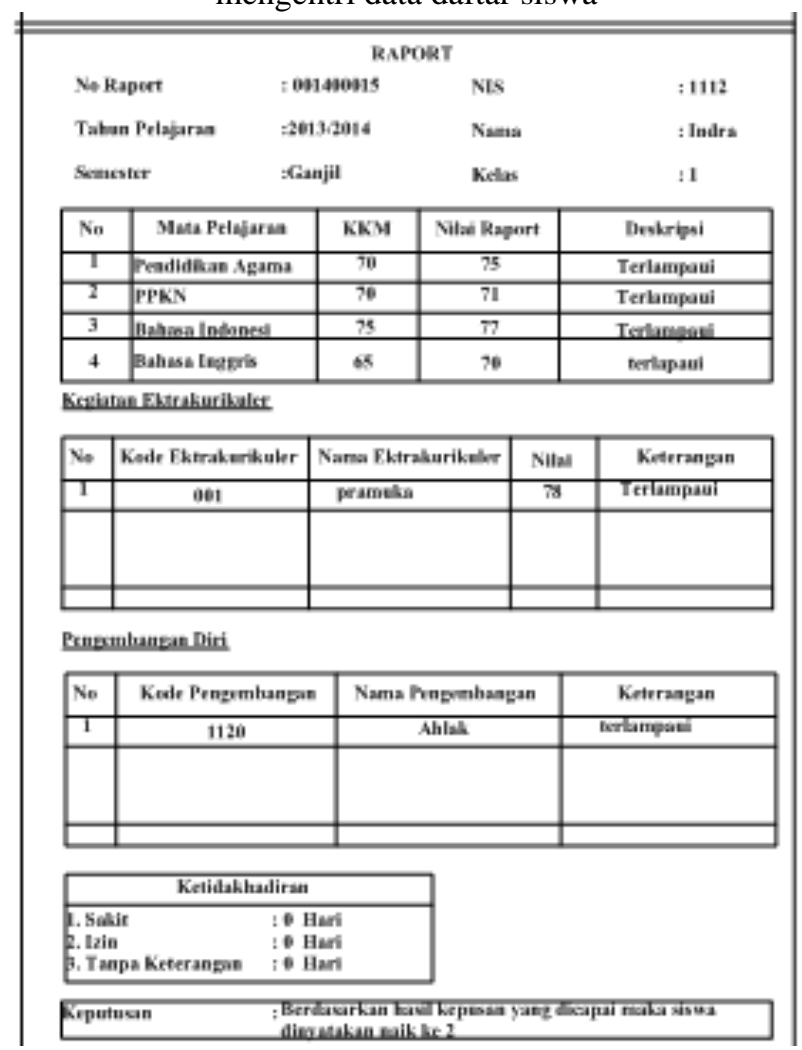

Gambar.8 Desain output nilai raport siswa

\section{DAFTAR PUSTAKA}

[1] Tata Sutabri, Analisis Sistem Informasi, Yogyakarta: 1998.

[2] Suhendra, Gunadi, Hariman, Visual Modeling Using UML dan Rational Rose, Penerbit Informastika Bandung : Bandung, 2002.

[3] Munawar, Pemodelan Sistem Informasi, Jakarta : Graha Ilmu, 2005.

[4] Whitten, Jeffery, Metode Design dan Analisis Sistem, Yogyakarta : edisi 6,20 